\title{
APPRAISAL SYSTEM ANALYSIS IN ALADDIN'S DIALOGUES AS THE MAIN CHARACTER IN ALADDIN 2019 MOVIE
}

\author{
Asya Durrotun Nafisah ${ }^{1}$, Ujang Suyatman ${ }^{2}$, Deuis Sugaryamah ${ }^{3}$ \\ MAN 1 Kabupaten Cirebon ${ }^{1}$, UIN Sunan Gunung Djati Bandung ${ }^{2}$, \\ UIN Sunan Gunung Djati Bandung ${ }^{3}$
}

\begin{abstract}
Attitude has to do with evaluating things, people's characters, and their feelings. Attitude can be identified not only from the dialogues used by people in their daily life interaction but also from the characters' dialogues in a movie. This research takes attitude and its language functions in Aladdin as the main character in Aladdin 2019 movie. This research focuses on: 1) what attitudes are revealed from Aladdin, the main character in Aladdin 2019 movie? 2) What language functions of Aladdin's attitude in Aladdin 2019 movie? This research uses the qualitative method. There are two types of data, they are audiovisual and document; Aladdin 2019 movie and its movie script. The technique of collecting data in this research uses the audiovisual documentation study technique and the researcher conducted mixed stages from some of the theories of analyzing data. To analyze data, the researcher uses Appraisal System theory by Martin, Rose, and White. The result of this research shows; 1) Aladdin as the main character in Aladdin 2019 movie revealed three types of attitudes; affect, judgment and appreciation with 2) Aladdin's attitude revealed five language functions from seven language functions by M.A.K Halliday; representational function, interactional function, personal function, heuristic function, and regulatory function. Though all types of attitude revealed in the movie, yet the most salient attitude Aladdin shown is positive appreciation, and the language used in his expressions has a representational function.
\end{abstract}

Keywords: Appraisal System, Attitude, Affect, Judgment, Appreciation, Aladdin

\section{INTRODUCTION}

Language cannot be separated from grammar. Language and grammar are analogous to two sides of a coin that cannot be separated. According to Gerot \& Wignell (1994) grammar is a theory of language, of how language is put together and how it works. More particularly, it is the study of wordings. Wording is how to use it to select and combine the words.

Grammar always develop every time. Renewable grammar is a systemic functional grammar or systemic functional linguistic. This theory was first published by M.A.K Halliday in 1985. The difference between traditional grammar and functional grammar is the goal of grammar itself. If in traditional grammar, the focus is how the sentence be structured. However, functional grammar focuses on how are the meanings of the text realized.

Based on the statement above, language system has variety of meaning, and the most important component is the meta-functions. It has three classifications namely, ideational function, interpersonal function, and textual function. The interpersonal function are function which express a speaker's attitudes and judgments. (Gerot \& Wignell, 1994). 
According to Martin \& rose (1994) we use the resource of appraisal to negotiate our social relationship by telling how we feel about things and people in a statement. In other word, it telling what our attitudes are. Thus, attitude is the way a person reacting to something. Attitude is evaluating things, people, and feelings, it can be positive or negative, and implicit or explicit. There are three kinds of attitude, they are affect, judgment and appreciation. Affect is identifying how people express their feeling either good feeling or bad feeling, so it can be positive or negative. Second, judgment is a judge of character's people. As with affect, it can be positive or negative and it may be judged explicitly or implicitly. Third, appreciation is appreciating things, as with affect and judgment, it can be positive and negative.

Interpersonal meaning not only can be found in daily life, but also in movie. Movie is a modern form of literary works which is very popular. People around the world watch movie as their daily entertainment nowadays. As a literary work, character elements always presented as an important part of stories. A character will always have a dialogue that reflects the attitude of the character itself.

Research on the appraisal system is not the first time carried out, previously there have been several studies that using appraisal system theory, especially about attitude with different research objects. The recent study done by Nugraheni Woro Puspandari (2018) about "Interpersonal Resources in Academic Writing: Dominant Choices and Functions of Attitude, Engagement and Graduation". It focuses on what the choices of attitude, engagement, and graduation are in introduction section of doctoral theses and the functions of attitude, engagement, and graduation to construct arguments in introduction section of doctoral theses. It reveals that appreciation more dominant than judging human behavior (judgement) or expressing feeling (affect) in constructing argument for evaluating process.

Additionally, appraisal system also can be applied in news report as Maretha Dwiastuti Putri (2018) did about "An Appraisal Analysis of News Reports on Attacking Incidents in Indonesia's Newspaper: A Case of Pikiran Rakyat and The Jakarta Post". It aims to uncover the types of attitude systems used by local Indonesian media in news of attack incidents and to investigate the potential meaning that can be deduced from the attitude system.

Not only in academic writing and news report, appraisal system also can be applied in social media, especially about the rhetoric of Donald Trump in Twitter that has been done by Andrew S. Ross and David Caldwell (2020) entitled "Going Negative: An Appraisal Analysis of the Rhetoric of Donald Trump on Twitter. This research revealed Trump used negative appraisal system in many ways to attack his political opponent. Based on the previous study, there are several applications in the appraisal system including academic writing, news reports and social media. This Research become a complement to previous studies because it is identify a character of Aladdin in Aladdin 2019 movie.

According to CNN Indonesia, Aladdin 2019 movie is one of the liveaction movies that has met expectations in the movie industry. Aladdin 2019 movie was made based on Aladdin's folklore, from a collection of epic stories story of 1001 Nights. It tells the journey of Aladdin, an orphaned young man who falls in love with Princess Jasmine, befriends a wishfulfilling genie, and must save his kingdom from the Jafar group. This movie became the fifth best-selling film in 2019, and the 34th best-selling film of all time. In this research, researcher be more specific in identifying attitude and its language functions in the main actor dialogue, namely 
Aladdin. Thus, researcher aims to find out the attitude of Aladdin as the main character in his dialogue.

\section{LITERATURE REVIEWS}

Before understanding attitude, first must understand appraisal system. Because attitude is part of appraisal system. Appraisal system is a system of interpersonal meanings. According to Halliday in Martin \& rose (1994) we use the resource of appraisal to negotiate our social relationship by telling how we feel about things and people in a statement. In other word, it telling what our attitudes are. Thus, attitude is the way a person reacting to something. Attitude is evaluating things, people, and feelings, it can be positive or negative, and implicit or explicit. There are three kinds of attitude, they are affect, judgment and appreciation.

1. Affect

Affect is identifying how people express their feeling either good feeling or bad feeling, so it can be positive or negative. It can be expressed directly and indirectly. Affect is an assessment of both positive and negative that more focuses on the feeling felt. In addition, the affect is also divided into two things, namely the irrealist affect and the realist affect. Irrealist affect consist of fear, and desire (dis/ inclination), on the type of realist influence are divided into (1) un/ happiness, (2) in / security, and (3) dis / satisfaction.

\section{Judgment}

Judgment is a judge of things and character's people. Judgment is a matter of judgment which is more emphasized on the moral behavior of the speaker / interlocutor both evaluating positive and negative things about something being discussed. Judgment consists of social esteem (social appreciation) and social sanction (social sanctions). Social esteem consists of admire (positive) and criticize (negative). Social sanction consists of praise (positive) and condemn (negative).

\section{Appreciation}

Appreciation is appreciating things, as with affect and judgment, appreciation consists of positive and negative. It including reaction, composition, and valuation. Reaction is divided into impact (strong influence) and quality (nature). Impact (effect) is shown by exciting or boring reactions, while quality (quality) in the form of positive / negative reactions. Composition (composition) is divided into balance (balanced) and complexity. Balance is a unity, a dispute, whereas complexity is a simplicity. Valuation in the form of profound and shallow. Appreciation is an assessment of both positive and negative given in the form of a thing or object to something being discussed.

Therefore, in addition to attitude, the function of each dialogue delivered also needs attention. M. A. K Halliday (1973) divides language functions into seven:

1. Instrumental function

This function is related to the language used to communicate preferences, choices, desires, needs or to get things done.

2. Representational functions

This function puts the language to convey or request information. In other words, the language is used to declare information or provide a description.

3. Interactional function

In this function, language is used to interact and plan, develop, or maintain the discussion or activities of groups or social relations. 
4. Personal function

This function puts language as a medium to convey personal opinions, attitudes and feelings including the speaker's identity.

5. Heuristic function

Language is used to find out, learn, and discover. It includes running questions or comments about things.

6. Regulatory function

Language is used to influence the behavior of someone to persuade, command or ask. In other words, the language is used to control.

7. Imaginative function.

Language is used to create, explore, and entertain, consisting of stories and dramatizations, rhymes, poems, and riddles, nonsense and word play.

\title{
FINDINGS AND DISCUSSIONS
}

The following is the data and the analysis of this study:

\section{Dialogue 1}

\author{
You declare you see me dimly \\ Through a glass which will not shine, \\ Though I stand before you boldly, \\ Trim in rank and marking time.
}

"Equality" is a poem which talks about how Maya want to be equal with the other. "You declare you see me dimly" Maya begins this stanza used word "dimly" which has meaning not very brightly or clearly. Maya used word "dimly" as metaphor to compare about how the other see or the opinion of white people towards black people. Maya wants to depict that the existence of black people was dimly. The existence of black people is something which there but also not there by white people. Also in the second line "Through a glass which will not shine", Maya used phrase "glass which will not shine" which has meaning a transparent substance which not have a bright or light.

Maya used sentence "glass which will not shine" as a metaphor which explain that black people actually is something which has bright as like a glass. But the glass cannot shine because the slavery time. It means that, black people is something who has a characteristic to be shine but cannot because of the condition back then. Also in the third line "Though I stand before you boldly", Maya used sentence "stand before you boldly" which has meaning to be on your feet before you having a strong appearance. Maya used phrase "stand before you boldly" as a metaphor which compare about Maya or black people condition between white people. Maya wants to explain that even black people can be shine but white people was stand before them. It means that there is no way to make black people more shining than white people in that time.

\section{Dialogue 2}

You do own to hear me faintly

As a whisper out of range, 
While my drums beat out the message

And the rhythms never change.

Equality, and I will be free.

Equality, and I will be free.

Second stanza begins with "You do own to hear me faintly". Sentence "to hear me faintly" which has meaning to be aware of sound which came from me that cannot be clearly heard. Maya used phrase "to hear me faintly" as an auditory imagery which depict that black people in that time was not has a strong sound. Maya wants the reader also hear what she hear when the slavery make black people cannot do anything. Also in the second line "As a whisper out of range" Maya used phrase "whisper out of range" which has meaning to speak very quietly so the other cannot hear what she say. Maya also used phrase "whisper out of range" as an auditory imagery which has meaning that black people in that time has to say something very quietly because of white people. And Maya wants the readers also hear what she hear back then.

Also in the next line, Maya write that while she has a drum which beat out the message but the rhythms will never changes. Also Maya used a repetition with a phrase "Equality, and I will be free" which repeated twice in this stanza. Maya wants to emphasize about how Maya and black people want the equality. They want to be same with white people. Has the same rights, has the same work place and also the other things. They want to be free.

\section{Dialogue 3}

You announce my ways are wanton,

\section{That I fly from man to man,}

But if I'm just a shadow to you, Could

you ever understand?

Third stanza begins with "You announce my ways are wanton" word "wanton" which has meaning causing harm or damage deliberately and for no acceptable reason. Maya used word "wanton" as a metaphor which compare about the ways of black people or Maya. The way which Maya or black people walk on is a harm way or something which can make them damage. Also in the second line "That I fly from man to man", Maya used phrase "fly from man to man" which has meaning come to every man in that area. Maya used phrase "fly from man to man" as a metaphor which compare the condition of black women in that time which has to come to every man. In slavery time, black women is someone who used as a breeding women. Also someone who can fulfill the desire of white people.

Maya wants to explain that black women in that time is like a women which can to be calling as a whore. But, in the next line "But if I'm just a shadow to you" Maya used a word "shadows" which has meaning the dark shape that something form makes on a surface. Maya used word "shadows" as a metaphor which compare about the condition of black women in that time. Black women in that time was like something bad, something black, something which has not value for white people.

\section{Dialogue 4}

We have lived a painful history, We know the shameful past, 
But I keep on marching forward, And

you keep on coming last.

Equality, and I will be free.

Equality, and I will be free.

Fourth stanza begins with "We have lived a painful history" phrase "painful history" which has meaning an event in the past or something which hurt. Maya used word "painful" as an organic imagery which used to makes the reader also feels what Maya feels when slavery time. Everything in slavery time make them feels hurt and it is something painful. Also Maya used phrase "painful history" as a metaphor which compare about the condition of black people which it is a painful event in the past. Maya wants to depict that their live when slavery time is a painful event in the past.

"We know the shameful past" Also Maya used phrase "shameful past" which has meaning something that make you feel ashamed which happen in the past. Maya used word "shameful" as an organic imagery, which invite the reader to feels what Maya feels in the past. That Maya was very ashamed because of the past of their history. But, in the next line "But I keep on marching forward" Maya states that she was keep on "marching forward" which has meaning to walk stiff regular steps like soldier toward a place or position that is in front. Maya used phrase "marching forward" as a metaphor which compare about the steps of black people to get a freedom was like a marching which come forward. They always steps forward to get their freedom. Also in this stanza, Maya used a repetition with phrase "Equality, and I will be free" which repeated twice in the end of the stanza.

\title{
Dialogue 5
}

\author{
Take the blinders from your vision, Take \\ the padding from your ears \\ And confess you've heard me crying, \\ And admit you've seen my tears.
}

Sixth stanza begins with "Take the blinders from your vision" phrase "blinders from your vision" which has meaning something which is excellent from the ability to see. Maya used phrase "blinders from your vision" as a metaphor which compare the condition of black people and white people. When black people want to be free they are take the great or excellent vision of white people so they can have equality with white people. Also in the next line "Take the padding from your ears" Maya used phrase "padding from your ears" which has meaning something or material that placed inside your ears. Maya used phrase "padding from your ears" as metaphor which compare about the condition of black people which take something from white people to make them equal.

Also in the next line "And confess you've heard me crying" Maya used phrase "heard me crying" which has meaning a sound which hear by the ear. Maya used word "heard" as auditory imagery which invite the reader to hear Maya's crying because of slavery time. Maya also wants the reader to feels and hear what she want they to hear. In the next line "And admit you've seen my tears", Maya used a phrase "seen my tears" as a visual imagery. Maya invites the reader to see the tears of black people in slavery time. 


\title{
Dialogue 6
}

\author{
Hear the tempo so compelling, Hear \\ the blood throb in my veins. \\ Yes, my drums are beating nightly, And \\ the rhythms never change. \\ Equality, and I will be free. \\ Equality, and I will be free.
}

Seventh stanza begins with "Hear the tempo so compelling" phrase "hear the tempo" which is an auditory imagery. "Hear the blood throb in my veins" The next line also there is an auditory imagery with the phrase "hear the blood". In the next line there is line "Yes, my drums are beating nightly" word "beating" which is an auditory imagery. The first line to the third line used an auditory imagery which has meaning or function to make the reader also hear what Maya hear back then. Maya invites the reader to know the condition in the slavery time by hearing. Also in the last stanza, Maya used a repetition of phrase "Equality, and I will be free" which repeated twice. The phrase "Equality, and I will be free" was repeated in every stanza in this poem. Which Maya used as an emphasizing about how black women want the equality for free. The theme of poem "Equality" is hopes of black women to be equal with white women.

Maya uses the repetition to emphasize that Maya Angelou wants to be free from racism and wants to be equal with everyone. Maya uses pronoun "I" to describe black women as herself. And she uses pronoun "You" to represent white women. This poem has theme about struggle to get the equality. Maya wants to explain to the readers that black women wants to be equal with white women. Maya also creates a sense of equality to make a strong massage for equal rights between everyone.

"Equality" is a poem which describe how black women want to be free and equal with white people. Maya used phrase "painful history", "shameful past" which explain about how pain the history of black women against racism in United States. Maya wants to depict how hard the struggle of black women against racism in United States. According to Humm (1986, p. 22) through literary feminist criticism will be described an oppression toward woman in literary work. It means that we can see the oppression toward woman when we used literary feminist criticism when analyze the literary work. Maya also states that "equality, and I will be free" to describe how black women wants equality to be free. They wants to be same with white people. They wants the racism deleted in United States and they will be free.

Equality is about the different treatment which experienced by black people in their society. They experienced bad treatments from the society because of their color skin. It is also experienced by Maya as black people. She experienced inequality since when she lived with her grandmother in Stamp, Arkansas. As (Stewart, 2009) states:

"These early years in Stamps were largely happy ones. But as loved as Maya felt by Momma and Uncle Willie, she was learning that there was ugliness about the town, too. Like the rest of south in the 
1930s, racial inequality was normal. Although slavery had been abolished since President Abraham Lincoln signed the

Emancipation Proclamation in 1863, little had changed for African-

Americans in the following seventy some years".

Maya had experienced inequality since she was child. The different treatment of the society also happened when she and Bailey go to a theater to watching a movie. They cannot enter the theater because they are black people but the ticket seller took their money. In that time there are white girls who also bought a ticket, the ticket seller gave the girl the ticket and ask them politely to watch the movie. In graduation day, White politician said that if white people school in Arkansas they will get many opportunities for their work place. The politician said that white people can be an artist, scientist, and other great work. Different with black people the opportunities of their careers is as a maids, handymen, and if they are very lucky they could be athletes (Stewart, 2009) .

Those are some unequal treatment of the society towards black people. Because of those experienced Maya wants to get the same treatment as like white people. She represent the feeling through this poems. She wants to be equal with white people, she wants black people have same right with other people. Through this poems, Maya wants to explain that black people struggling against racism because of their color skin.

\section{CONCLUSION}

Maya Angelou as black women poet depict about the struggle of black women in United States through her poems. Maya Angelou employs the intrinsic elements of poetry in her poem entitles "Equality" to show black women struggle. In "Equality", Maya depict about how black women want to be equal with white people. Maya uses auditory imagery to explain their voice which want to be equal with white people. Maya also uses metaphor to explain the condition of black women, and the reason why they want to be equal. Maya wants to represent that black women in that era has a clash with white people. White people treats black women in a bad way because they are consider black women as slave. White people treats black women in a bad way because their color skin. Maya wants to explain through her poem "Equality" that black women struggling against racism.

\section{REFERENCES}

Abrams, M. (1999). A Glossary of Literary Terms. London: Oxford University Press. Collins, P. H. (2000). Black Feminist Thought:Knowlede, Consciousness, and the Politics of Empowerment Second Edition. New York: Routledge.

Hornby, A. S. (2010). Oxford Advanced Learner's Dictionary. New York: Oxford University Press.

Humm, M. (1986). Feminist Criticism . Great Britain: The Harvester Press.

Showalter, E. (2010). Feminist Criticism in the Wilderness. Chicago Journals, 184.

Stewart, G. B. (2009). Maya Angelou. New York: Gale Cengage Learning. 